\title{
IMPLEMENTASI SISTEM PAKAR UNTUK MENDIAGNOSIS PENYAKIT DENGAN GEJALA DEMAM MENGGUNAKAN METODE CERTAINTY FACTOR
}

\author{
Daniel, Gloria Virginia \\ Teknik Informatika Universitas Kristen Duta Wacana \\ Email: daniel_3490@yahoo.com, gloriavirginia@gmail.com \\ Soni Ananto \\ Dokter Umum
}

\begin{abstract}
Abstrak:
Sistem pakar untuk diagnosis penyakit dibangun dengan menerapkan metode certainty factor. Sistem tersebut memberikan hasil berupa kemungkinan penyakit yang dialami, prosentase keyakinan, serta solusi pengobatan berdasarkan faktafakta dan nilai keyakinan yang diberikan oleh pengguna dalam menjawab pertanyaan selama sesi konsultasi ketika menggunakan sistem ini. Implementasi sistem ini digunakan untuk mengevaluasi proses akuisisi pengetahuan dalam membangun basis pengetahuan.
\end{abstract}

Kata kunci : sistem pakar, certainty factor, akuisisi pengetahuan

\section{Pendahuluan}

Salah satu masalah di dalam dunia medis adalah adanya ketidakseimbangan antara pasien dan dokter. Selain itu sebagian besar dari masyarakat tidak terlatih secara medis, sehingga apabila mengalami gejala penyakit yang diderita belum tentu dapat memahami caracara penanggulangannya. Sangat disayangkan apabila gejala-gejala yang sebenarnya dapat ditangani lebih awal menjadi penyakit yang lebih serius akibat kurangnya pengetahuan. Dalam masyarakat, demam dikenal sebagai sebuah penyakit yang cukup umum terjadi. Hanya sedikit orang yang tahu bahwa demam sebenarnya adalah sebuah gejala dari berbagai kemungkinan penyakit.

Situasi tersebut dapat dihindari jika masyarakat memiliki sedikit pengetahuan tentang kesehatan. Pengetahuan dapat diperoleh dari buku-buku atau situs-situs internet yang membahas tentang kesehatan. Akan tetapi untuk mempelajari hal tersebut tidaklah mudah karena selain memerlukan waktu yang cukup lama untuk memahaminya, sumber-sumber 
tersebut juga belum tentu dapat mendiagnosis jenis penyakit seperti yang dilakukan oleh seorang dokter.

Oleh karena itu diperlukan suatu alat atau sistem yang lebih praktis dan memiliki kemampuan layaknya seorang dokter dalam mendiagnosis penyakit. Sistem tersebut adalah sistem pakar yang berusaha mengadopsi pengetahuan manusia ke dalam komputer agar dapat menyelesaikan masalah seperti yang biasa dilakukan oleh pakar. Untuk membuat sistem pakar lebih natural, certainty factor seringkali digunakan di dalamnya. Metode ini memberikan ruang pada pakar dalam memberikan nilai keyakinannya pada pengetahuan yang diungkapkannya. Sistem pakar tidak dimaksudkan untuk menggantikan peran seorang pakar sehingga dapat digunakan untuk menanggulangi keterbatasan jumlah pakar. Seorang dokter dapat dikatakan sebagai seorang pakar karena merupakan orang yang ahli di bidangnya dan memiliki kemampuan yang tidak dimiliki oleh orang lain.

Dalam membangun sebuah sistem pakar, dibutuhkan proses akuisisi pengetahuan, yaitu proses mengambil pengetahuan dari pakar untuk direpresentasikan ke dalam sistem komputer. Pengetahuan hasil proses akuisisi inilah yang kemudian menjadi pengetahuan dalam basis pengetahuan sebuah sistem pakar. Oleh karena itu, dapat dikatakan bahwa proses akuisisi pengetahuan yang dilakukan memiliki pengaruh yang besar terhadap kualitas basis pengetahuan, dimana kualitas basis pengetahuan memiliki pengaruh yang besar terhadap output sistem.

Penelitian ini akan membangun suatu sistem pakar dalam rangka mengevaluasi proses akuisisi pengetahuan yang dilakukan dalam membangun basis pengetahuan yang mengimplementasikan metode certainty factor. Proses evaluasi terhadap akuisisi pengetahuan dilakukan setelah performa sistem dievaluasi menggunakan 3 cara, yaitu evaluasi terhadap implementasi CF, evaluasi terhadap output sistem berdasarkan pakar, dan evaluasi terhadap output sistem berdasarkan user.

Oleh karena topik permasalahan tentang diagnose penyakit deman sangat luas, maka dalam penelitian ini akan dikenakan beberapa batasan sebagai berikut :

1. Sistem yang dibangun adalah sistem yang digunakan untuk melakukan diagnosis penyakit secara umum dan secara subyektif dirasakan oleh pasien bahwa dia mengalami gejala demam.

2. Gejala-gejala yang didiagnosis hanya berdasarkan pemeriksaan fisik dan tidak ada pemeriksaan penunjang seperti pemeriksaan laboratorium.

3. Jenis penanganan atau pengobatan yang dianjurkan hanya pengobatan sebagai pertolongan pertama dan simptomatis (menghilangkan gejala).

4. Diagnosis yang dilakukan hanya ditujukan untuk orang dewasa yang berusia 18 tahun ke atas. 


\section{Sistem Pakar}

Sistem pakar adalah sistem yang berusaha mengadopsi pengetahuan manusia ke komputer yang dirancang untuk memodelkan kemampuan menyelesaikan masalah seperti layaknya seorang pakar (Durkin, 1994). Tiga komponen utama yang terdapat pada setiap sistem pakar adalah basis pengetahuan, mesin inferensi, dan antar muka pengguna

\subsection{Akuisisi Pengetahuan}

Menurut Milton,N.R dalam bukunya akuisisi pengetahuan merupakan proses mengambil pengetahuan dari pakar atau sumber pengetahuan lainnya ke dalam sistem komputer untuk membangun basis pengetahuan. Terdapat tiga aspek dalam akuisisi pengetahuan, yaitu :

1. Knowledge capture

Knowledge capture adalah teknik yang digunakan ketika bertemu pakar. Teknik ini terdiri dari interview techniques, modelling techniques dan specialised techniques.

2. Knowledge analysis

Analisis pengetahuan ini merupakan proses mengidentifikasi elemen yang dibutuhkan dalam membangun basis pengetahuan. Terdapat 4 elemen penting dalam membangun basis pengetahuan, yaitu konsep, atribut, value/nilai dan relasi.

3. Knowledge modelling

Knowledge modelling yaitu menciptakan cara yang berbeda dalam mengubah dan menampilkan basis pengetahuan. Terdiri dari bagian-bagian seperti pohon (trees), matriks, map, timeline, frame dan knowledge page.

\subsection{Certainty Factor}

Faktor Kepastian (Certainty Factor) menyatakan kepercayaan dalam sebuah kejadian (atau fakta atau hipotesis) berdasarkan bukti atau penilaian pakar (Turban, 2005). Certainty Factor menggunakan suatu nilai untuk mengasumsikan derajad keyakinan seorang pakar terhadap suatu data. Certainty Factor memperkenalkan konsep keyakinan dan ketidakyakinan yang kemudian diformulakan dalam rumusan dasar sebagai berikut :

$$
C F[P, E]=M B[P, E]-M D[P, E]
$$

Keterangan :

$$
\begin{array}{ll}
\text { CF } & \text { : Certainty Factor } \\
\text { MB } & \text { : Measure of Belief } \\
\text { MD } & \text { : Measure of Disbelief } \\
\text { P } & \text { : Probability } \\
\text { E } & \text { : Evidence (Peristiwa/Fakta) }
\end{array}
$$


Berikut ini adalah deskripsi beberapa kombinasi Certainty Factor terhadap berbagai kondisi :

- Certainty Factor untuk kaidah dengan premis tunggal (single premis rules):

$$
\begin{aligned}
\mathrm{CF}(\mathrm{H}, \mathrm{E}) & =\mathrm{CF}(\mathrm{E})^{\star} \mathrm{CF}(\text { rule }) \\
& =\mathrm{CF}(\text { user })^{\star} \mathrm{CF}(\text { pakar })
\end{aligned}
$$

- Certainty Factor untuk kaidah dengan premis majemuk (multiple premis rules):

$$
\begin{aligned}
& \mathrm{CF}(\mathrm{A} \text { AND B })=\operatorname{Minimum}(\mathrm{CF}(\mathrm{a}), \mathrm{CF}(\mathrm{b})) * \mathrm{CF}(\text { rule }) \\
& \mathrm{CF}(\mathrm{A} \text { OR B })=\text { Maximum }(\mathrm{CF}(\mathrm{a}), \mathrm{CF}(\mathrm{b})){ }^{*} \mathrm{CF}(\text { rule })
\end{aligned}
$$

- Certainty Factor untuk kaidah dengan kesimpulan yang serupa (similarly concluded rules) :

$$
\mathrm{CF}_{\text {COMBINE }}\left(\mathrm{CF}_{1}, \mathrm{CF}_{2}\right)=\mathrm{CF}_{1}+\mathrm{CF}_{2}^{*}\left(1-\mathrm{CF}_{1}\right)
$$

\section{Implementasi dan Evaluasi Sistem}

Sistem pakar yang dibangun merupakan rule-based expert system yang menerapkan metode Certainty Factor. Sebelum melakukan evaluasi terhadap proses akuisisi pengetahuan, performa sistem perlu dievaluasi terlebih dahulu. Performa sistem dievaluasi dengan tiga cara, yaitu evaluasi secara teknis untuk menilai ketepatan implementasi certainty factor, evaluasi terhadap output sistem berdasarkan pakar, dan terakhir evaluasi terhadap output sistem berdasarkan user.

\subsection{Evaluasi Performa Sistem}

\subsubsection{Implementasi Metode Certainty Factor (CF)}

Pada sesi konsultasi sistem, user diberi pilihan jawaban yang masing-masing memiliki bobot sebagai berikut :

1) Untuk dua pilihan jawaban :

$$
\begin{array}{ll}
\text { - Tidak } & =0 \\
\text { - Ya } & =1
\end{array}
$$

2) Untuk lima pilihan jawaban :
- Tidak
$=0$
- Sedikit yakin
$=0,4$ 


$\begin{array}{ll}\text { - Cukup yakin } & =0,6 \\ \text { - Yakin } & =0,8 \\ \text { - Sangat yakin } & =1\end{array}$

Nilai 0 menunjukkan bahwa user tidak mengalami gejala seperti yang ditanyakan oleh sistem. Semakin user yakin bahwa gejala tersebut memang dialami, maka semakin tinggi pula hasil prosentase keyakinan total yang diperoleh. Proses penghitungan prosentase keyakinan diawali dengan pemecahan sebuah kaidah (rule) yang memiliki premis majemuk, menjadi kaidah-kaidah (rules) yang memiliki premis tunggal. Kemudian masing-masing rule baru dihitung CF nya dengan menggunakan Persamaan (2.2) sehingga setelah diperoleh nilai CF untuk masing-masing rule, kemudian nilai CF tersebut dikombinasikan dengan Persamaan (2.5). Sebagai contoh, ikut ini adalah proses pemberian bobot pada setiap premis (gejala) hingga perolehan prosentase keyakinan untuk penyakit Tuberkulosis.

\section{Kaidah 1:}

IF Demam

AND Batuk

AND Batuk lebih dari 4 minggu

THEN Tuberkulosis

Langkah pertama, pakar menentukan nilai CF untuk masing-masing gejala sebagai berikut :

$\begin{array}{ll}\mathrm{CF}_{\text {pakar }} \text { (Demam) } & =0,5 \\ \mathrm{CF}_{\text {pakar }} \text { (Batuk) } & =0,5 \\ \mathrm{CF}_{\text {pakar }} \text { (Batuk lebih dari } 4 \text { minggu) } & =0,6\end{array}$

Misalkan user memilih jawaban sebagai berikut :

$\begin{array}{lll}\text { Demam } & =\text { Ya } & =1 \\ \text { Batuk } & =\text { Yakin } & =0,8 \\ \text { Batuk lebih dari } 4 \text { minggu } & =\text { Sedikit Yakin } & =0,4\end{array}$

Kaidah awal yang memiliki 3 premis dipecah menjadi kaidah yang memiliki premis tunggal, sehingga menjadi :

Kaidah 1.1

IF Demam

THEN Tuberkulosis 


\section{Kaidah 1.2}

IF Batuk

THEN Tuberkulosis

\section{Kaidah 1.3}

IF Batuk lebih dari 4 minggu

THEN Tuberkulosis

Kaidah-kaidah yang baru tersebut kemudian dihitung nilai CFnya dengan mengalikan $\mathrm{CF}_{\text {pakar }}$ dengan $\mathrm{CF}_{\text {user }}$ menjadi :

$\begin{array}{lll}\text { CF } 1.1 & =0,5^{\star} 1 & =0,5 \\ \text { CF } 1.2 & =0,5^{\star} 0,8 & =0,4 \\ \text { CF } 1.3 & =0,6^{\star} 0,4 & =0,24\end{array}$

Kombinasikan CF 1.1 dengan CF 1.2 dengan rumus berikut :

$$
\begin{aligned}
& \mathrm{CF}_{\text {COMBINE }}\left(\mathrm{CF}_{1}, \mathrm{CF}_{2}\right)=\mathrm{CF}_{1}+\mathrm{CF}_{2}{ }^{*}\left(1-\mathrm{CF}_{1}\right) \text {, sehingga menjadi } \\
& \mathrm{CF}_{\text {COMBINE }}(\mathrm{CF} 1.1, \mathrm{CF} 1.2)=0,5+0,4^{*}(1-0,5)=0,7=\mathrm{CF}_{\text {old }}
\end{aligned}
$$

Kombinasikan $\mathrm{CF}_{\text {old }}$ dan CF 1.3

$$
\mathrm{CF}_{\text {COMBINE }}\left(\mathrm{CF}_{\text {old }}, \mathrm{CF} 1.3\right)=0,7+0,24^{*}(1-0,7)=0,772
$$

Prosentase keyakinan $=\mathrm{CF}_{\text {COMBINE }}{ }^{\star 100 \%}$

$$
=77,2 \%
$$

Kasus ini juga diuji cobakan ke dalam sistem, dan sistem memberikan output sama yaitu $77,2 \%$. Dengan demikian dapat dikatakan bahwa perhitungan Certainty Factor yang dilakukan oleh sistem tepat.

\subsubsection{Evaluasi Output Sistem Berdasarkan Pakar}

Ketepatan hasil analisis sistem diuji dengan melakukan penilaian terhadap output sistem berdasarkan input yang diberikan user, yaitu apakah output yang dihasilkan sudah tepat bila dinilai dari sudut pandang seorang pakar kedokteran.Ananto dan dr. Wiji Lestari. Tabel 1 dan 2 ini adalah ringkasan hasil penilaian dari 25 kasus yang diujikan kepada kedua penguji. 
Tabel 1 Hasil Analisis Sistem (Oleh dr. Soni Ananto)

\begin{tabular}{|c|c|}
\hline Kasus & $\begin{array}{c}\text { Ketepatan } \\
\text { (\%) }\end{array}$ \\
\hline 1 & 70 \\
\hline 2 & 70 \\
\hline 3 & 90 \\
\hline 4 & 80 \\
\hline 5 & 80 \\
\hline 6 & 60 \\
\hline 7 & 80 \\
\hline 8 & 70 \\
\hline 9 & 80 \\
\hline 10 & 70 \\
\hline 11 & 70 \\
\hline 12 & 80 \\
\hline 13 & 70 \\
\hline
\end{tabular}

\begin{tabular}{|c|c|}
\hline Kasus & $\begin{array}{c}\text { Ketepatan } \\
\text { (\%) }\end{array}$ \\
\hline 14 & 60 \\
\hline 15 & 80 \\
\hline 16 & 80 \\
\hline 17 & 80 \\
\hline 18 & 90 \\
\hline 19 & 60 \\
\hline 20 & 80 \\
\hline 21 & 50 \\
\hline 22 & 90 \\
\hline 23 & 80 \\
\hline 24 & 60 \\
\hline 25 & 70 \\
\hline $\begin{array}{l}\text { Rata- } \\
\text { Rata }\end{array}$ & 74 \\
\hline
\end{tabular}

Tabel 2 Hasil Analisis Sistem (Oleh dr.Wiji Lestari)

\begin{tabular}{|c|c|}
\hline Kasus & $\begin{array}{c}\text { Ketepatan } \\
\text { (\%) }\end{array}$ \\
\hline 1 & 70 \\
\hline 2 & 75 \\
\hline 3 & 80 \\
\hline 4 & 70 \\
\hline 5 & 78 \\
\hline 6 & 55 \\
\hline 7 & 65 \\
\hline 8 & 60 \\
\hline 9 & 85 \\
\hline 10 & 60 \\
\hline 11 & 70 \\
\hline 12 & 77 \\
\hline 13 & 68 \\
\hline
\end{tabular}

\begin{tabular}{|c|c|}
\hline Kasus & $\begin{array}{c}\text { Ketepatan } \\
\text { (\%) }\end{array}$ \\
\hline 14 & 50 \\
\hline 15 & 75 \\
\hline 16 & 70 \\
\hline 17 & 65 \\
\hline 18 & 93 \\
\hline 19 & 45 \\
\hline 20 & 80 \\
\hline 21 & 45 \\
\hline 22 & 80 \\
\hline 23 & 60 \\
\hline 24 & 70 \\
\hline 25 & 76 \\
\hline $\begin{array}{l}\text { Rata- } \\
\text { Rata }\end{array}$ & 68,88 \\
\hline
\end{tabular}


Dari data tabel, tampak bahwa kedua penguji menilai output sistem cukup baik. Dr. Soni menilai ketepatan output sistem 74\% sedangkan dr. Wiji menilai 68,88\%.

\subsubsection{Evaluasi Output Sistem Berdasarkan User}

Selain analisis sistem yang dilakukan oleh pakar juga dilakukan pengujian sistem oleh user. Di sini, user dimiinta untuk mencoba sistem kemudian diberikan kuisioner yang terdiri dari 4 pertanyaan. Sampel yang digunakan adalah 20 responden yang dipilih secara acak. Tujuan dari analisa ini adalah untuk mengetahui performa sistem secara umum. Berikut ini adalah analisa data kuisioner :

1. Sistem sudah cukup membantu dalam menemukan kemungkinan penyakit berdasarkan gejala-gejala yang dialami.

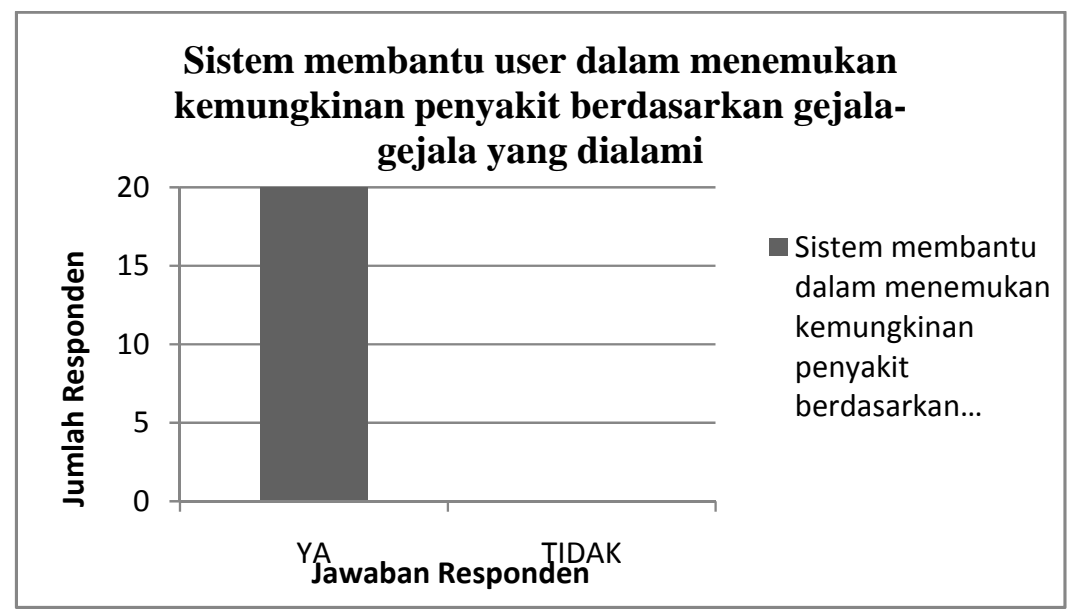

Gambar 1

Sistem membantu user dalam menemukan kemungkinan penyakit berdasarkan gejala-gejala yang dialami 
2. Info (penjelasan) yang diberikan oleh sistem

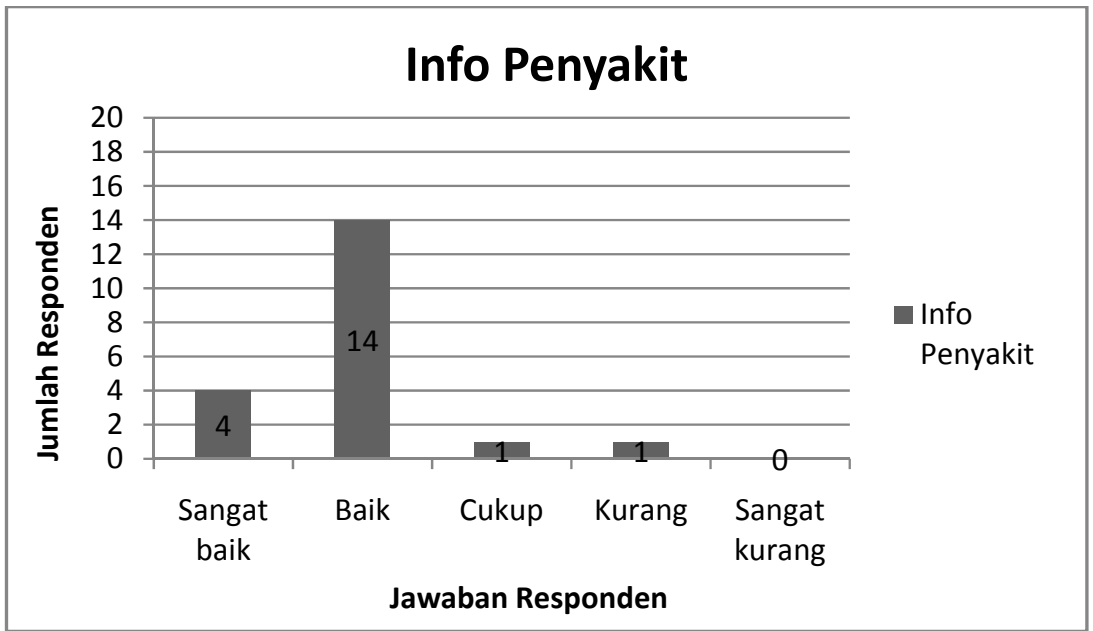

Gambar 2

Info penyakit yang diberikan oleh sistem

3. Manfaat solusi untuk user

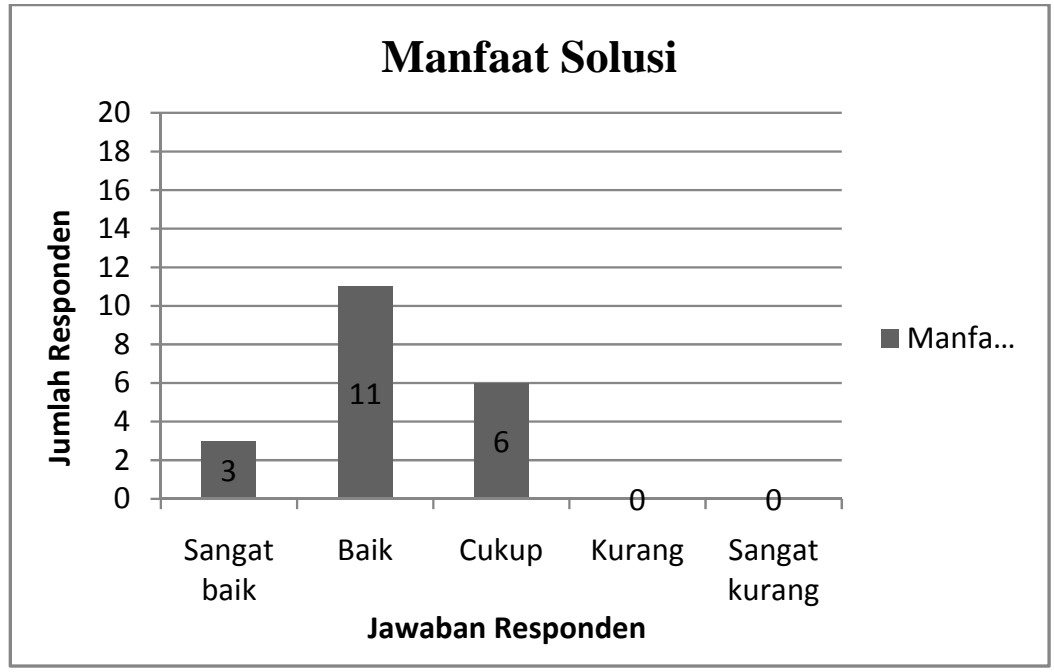

Gambar 3

Manfaat solusi untuk user 
4. Komentar/saran dari user

Tabel 3 Komentar responden

\begin{tabular}{|c|l|c|}
\hline No & \multicolumn{1}{|c|}{ Kategori } & Jumlah Responden \\
\hline 1. & Sistem sudah baik & 11 responden \\
\hline 2. & Kelengkapan data & 10 responden \\
\hline 3. & Tampilan/desain sistem & 4 responden \\
\hline
\end{tabular}

Dari keempat hasil evaluasi data kuisioner di atas, dapat disimpulkan bahwa performa sistem cukup baik.

\subsection{Evaluasi Akuisisi Pengetahuan}

\section{a. Knowledge Capture}

Pada knowledge capture, teknik atau metode yang digunakan untuk meng-capture pengetahuan pakar adalah berupa studi literatur dan wawancara langsung terhadap pakar (interview techniques). Wawancara yang dilakukan merupakan wawancara terarah (directed interview), yang dilakukan oleh pakar (dokter) dan knowledge engineer dengan cara mendiskusikan hubungan antara gejala-gejala yang dialami pasien dengan kemungkinan penyakit serta cara mendiagnosis yang dilakukan oleh pakar secara umum. Proses wawancara yang telah dilakukan termasuk semi-structured interview, di mana proses wawancara tersebut dilakukan dengan persiapan yang meliputi jadwal wawancara (konsultasi), pertanyaan yang akan diajukan termasuk perlengkapan yang dibutuhkan untuk proses wawancara seperti catatan dan alat perekam. Selain pertanyaan yang telah dipersiapkan juga meliputi pertanyaan tambahan (supplementary questions) pada saat wawancara dilakukan.

\section{b. Knowledge Analysis}

Pada tahap ini, knowledge engineer mengidentifikasi konsep-konsep dan relasinya dari pengetahuan yang didapat melalui proses knowledge capture yang telah dilakukan. Hasil dari proses identifikasi tersebut adalah jenis penyakit, gejala penyebab penyakit tersebut dan hubungan antara penyakit dan gejalanya.

\section{c. Knowledge Modelling}

Dalam proses analisis yang dilakukan, pakar dan knowledge engineer bersama-sama membangun basis pengetahuan yang kemudian diterjemahkan ke dalam berbagai model antara lain tree, map dan matriks. 


\section{Pembahasan}

Berhubungan dengan proses akuisisi pengetahuan, walaupun sistem yang dibangun mampu memberikan performa yang cukup baik dalam menganalisis penyakit berdasarkan gejala-gejala fisik yang dialami, pada kenyataannya proses akuisisi yang telah dilakukan tidak mudah. Selain masalah waktu, dari metode interview techniques yang dilakukan terdapat beberapa kendala terutama dari sisi knowledge engineer dalam mengambil dan menerjemahkan pengetahuan. Pengetahuan tersebut adalah pengetahuan pakar yang bersifat dalam (deep/tacit) seperti pengetahuan yang berkaitan dengan pengalaman, intuisi, keterampilan, persepsi pribadi dan perasaan.

Selain itu, metode yang lain seperti observasi, tidak dapat dilakukan karena masalah kode etik kedokteran, yaitu adanya privasi antara konsultasi pasien dengan dokter. Sebenarnya apabila metode observasi dapat dilakukan kemungkinan besar kualitas basis pengetahuan akan meningkat karena melalui observasi langsung terhadap konsultasi pasien dan dokter, deep knowledge pakar dan proses berpikirnya kemungkinan besar dapat ditangkap.

\section{Kesimpulan dan Saran}

Berdasarkan hasil implementasi dan evaluasi sistem, dapat disimpulkan bahwa proses akuisisi pengetahuan yang dilakukan sudah cukup efektif. Hal ini dikuatkan dengan hasil evaluasi terhadap ketepatan output sistem, baik berdasarkan pakar maupun user. Ketepatan output sistem tersebut merupakan salah satu indikator bahwa basis pengetahuan sistem cukup baik. Sedangkan basis pengetahuan sistem dapat dibangun dengan baik jika proses akuisisi pengetahuan yang dilakukan tepat.

Meskipun demikian, pada kenyataannya proses akuisisi yang dilakukan tidak mudah karena terdapat berbagai macam kendala seperti masalah waktu, pengetahuan pakar yang bersifat dalam (deep/tacit), kesulitan yang dialami knowledge engineer dalam memahami pengetahuan di bidang kedokteran serta metode observasi yang tidak dapat dilakukan karena masalah kode etik kedokteran.

Saran penulis untuk pengembangan sistem ini di masa yang akan datang adalah menambah kemungkinan penyakit dan gejala yang tidak hanya untuk kategori demam saja. Sistem juga perlu ditambah heuristic knowledge dan analisa pemeriksaan laboratorium untuk memperkuat diagnosis awal sehingga sistem semakin akurat dalam melakukan diagnosis penyakit. Selain itu sistem perlu dikembangkan dengan tampilan yang lebih menarik lagi.

\section{Daftar Pustaka}

[1] Alsagaff, Hood (1989). Ilmu penyakit paru. Airlangga University Press, Surabaya.

[2] Durkin, John (1994). Expert system design and development. Prentice Hall International Edition, Inc., London. 
[3] Giarratano, Joseph C., dan Gary D. Riley (2005). Expert systems principles and programming, $4^{\text {th }}$. edition. Massachusetts: Course Technology, Boston.

[4] Harsono dkk (1989). Pedoman diagnosis dan terapi untuk paramedis di puskesmas. Fakultas Kedokteran UGM, Yogyakarta.

[5] Jakob, B., Benn, Cristoph, Senturias, E. (2003). Penyembuhan yang mengutuhkan. Kanisius, Yogyakarta.

[6] Kusrini (2006). Sistem pakar teori dan aplikasi. Andi Offset, Yogyakarta.

[7] Martin, J., Oxman, S. (1992). Building expert systems. Prentice Hall, New Jersey.

[8] Milton, N.R (2007). Knowledge acquisition in practice. Springer, London.

[9] Nugroho, B. (2008). Aplikasi sistem pakar dengan php dan editor dreamweaver. Gava Media, Yogyakarta.

[10] Soeparman DR, Sukatan, U., Dr., Prof, et al. (1990). IImu penyakit dalam jilid II. Balai Penerbit FKUI, Jakarta.

[11] Turban, E., Aronson, J.E. (2001). Decision support systems and intelligent systems, $6^{\text {th }}$. Edition; Prentice Hall International Edition, New Jersey.

[12] Werner, C. T., Maxwell, J. (2007). Ketika tidak ada dokter. Hesperian, California. 